\title{
Biochemical analysis of elephant foot yam (Amorphophallus paeoniifolius) lacto-pickle with probiotic Lactobacillus plantarum
}

\author{
Sudhanshu S. Behera ${ }^{1}$ - Smita H. Panda ${ }^{2}$ - Sandeep K. Panda ${ }^{3}$ • Awanish Kumar ${ }^{1}$ (I)
}

Received: 22 October 2018 / Accepted: 7 February 2019 / Published online: 14 March 2019

(C) Università degli studi di Milano 2019

\begin{abstract}
Lacto-pickles are tangy, crisp, and definitely not intimidating to eat. We previously standardized fermentations of elephant foot yam (EFY) into lacto-pickle using different fermentation specifications. The aims of this work were to perform the effect of starter culture strain Lactobacillus plantarum (MTCC-1325) on chemical and biochemical properties of EFY lacto-pickle. In this study, we conducted the preprocessing of blanched EFY blocks/cubes in brine $(\mathrm{NaCl}, 8 \%, w / v)$ and inoculated with the starter culture (L. plantarum MTCC-1325). The impact of L. plantarum (MTCC-1325) during lacto-pickle fermentation and its effect on the antioxidant property, structural characterization (scanning electron microscopy (SEM) and infrared spectroscopy (FTIR)), sensory analysis, and volatilome profile (gas chromatography and mass spectrometry (GC-MS)) of EFY lacto-pickle were determined. Inoculated samples showed significantly higher acidification of the brine, reaching a $\mathrm{pH}$ of 2.67 and titratable acidity (TA) of $2.8 \mathrm{~g} / \mathrm{L}$ within 42 days of fermentation, suggesting potential antioxidant activity. The FTIR technique revealed the changes/deformation of functional groups and SEM study suggested the interaction/adhesion between starter culture L. plantarum (MTCC 1325) on EFY lacto-pickle. The starter culture used clearly influenced volatile organic compounds (VOCs) profiles of EFY lacto-pickle. Moreover, EFY lacto-pickle produced with the starter culture significantly perceived a positive response in the overall acceptance. Overall results indicated the successful and accelerated EFY lacto-pickle was achieved when using L. plantarum (MTCC-1325) as starter culture and thus the possible use of this fortified product by the consumers in their diet.
\end{abstract}

Keywords Submerged fermentation $\cdot$ Elephant foot yam lacto-pickle $\cdot$ Proximate composition $\cdot$ Sensory evaluation

\section{Introduction}

Elephant foot yam (EFY) (Amorphophallus paeoniifolius Densst.) Nicolson (Araceae) is a highly salubrious but underutilized tropical tuber crop. The tuber is rich in nutrients and is an adequate source of mineral, protein, nutrients, and

Electronic supplementary material The online version of this article (https://doi.org/10.1007/s13213-019-01449-8) contains supplementary material, which is available to authorized users.

\section{Awanish Kumar}

drawanishkr@gmail.com; awanik.bt@nitrr.ac.in

1 Department of Biotechnology, National Institute of Technology, Raipur, Chhattisgarh 492010, India

2 Department of Zoology, North Orissa University, Mayurbhanj, Odisha, India

3 School of Biotechnology, KIIT University, Bhubaneswar, Odisha, India starch (Behera and Ray 2016). EFY also forms an integral part of the staple food system for a population of around 500 million people globally (Muniz et al. 2008). The rural and tribal people mostly consume the tuber crop either in raw, boiled, or baked form (Di Cagno et al. 2013). EFY lacto-pickling is a novel process to pickle the tuber without any addition of oil and spices; in turn, pickling is done organically with lactic acid bacteria (LAB) (Sivakumar et al. 2010; Ray and Behera 2016). The LAB is a group of organisms (gram-positive and non-sporulating rods or cocci) that ferment sugar (i.e., glucose) to lactic acid (LA). Lactobacillus plantarum is an efficient LAB microorganism which can be used as a starter culture for preparation of EFY lacto-pickle. This species is known to improve the intestinal microflora and inhibit the growth of pathogens, (i.e., Escherichia coli, Salmonella, and Staphylococcus). Further, the group of LAB are probiotics in nature and is often experienced/encountered in human gastrointestinal tracts that confers various health benefits to consumers (Reddy et al. 2014; Behera et al. 2018a). 
In our previous work, we have a standardized (response surface methodology (RSM) technique) the submerged fermentations (SmF) of EFY into lacto-pickle using different fermentation specifications (Behera et al. 2018). In continuation of the above-mentioned study, the current study focuses on analytical/biochemical ( $\mathrm{pH}$, titratable acidity (TA), LA, starch, and total sugar) and proximate composition (organic matter, ash, fat, crude protein, gross energy, moisture, and dietary fiber) of EFY lacto-pickle. The antioxidant property and sensory analysis/attributes (aroma, texture, flavor, color/ appearance, taste, and after taste) of the EFY lacto-pickle was judged. Analysis of volatile compounds (GC-MS analysis) and structural characterization (SEM and FTIR) of the EFY lacto-pickle was also conducted for evaluating the adhesion and interaction studies.

\section{Materials and methods}

\section{EFY roots}

EFY roots/tubers (cultivar: IGAM-1) from the experiential field/farm of Indira Gandhi Krishi Vishwavidyalaya (IGKV), Raipur, Chhattisgarh (CG) (located center-east of India), were used in experiments. Freshly harvested and unbruished EFY roots were collected during the season/month of November 2016 with night and day temperature were $14 \pm 2{ }^{\circ} \mathrm{C}$ and 28 $\pm 2{ }^{\circ} \mathrm{C}$, respectively. The roots/tubers were used in a period of $24 \mathrm{~h}$ later harvest.

\section{Propagation of starter culture}

Lactobacillus plantarum (MTCC-1325) was maintained on the Man, Rogosa, and Sharpe (MRS) agar (Merck KGaA, Darmstadt, Germany) inclines/slants at $4{ }^{\circ} \mathrm{C}$ in a refrigerator (Panda and Ray 2008). The L. plantarum (MTCC-1325) culture was the stock culture (viable) of the Institute of Microbial Technology (IMTEC), Chandigarh (a union territory of India). Sweet grapes (var. Bangalore blue) (100 g) of good quality was chosen and cleaned thoroughly by running tap water to discard the impurities. A mixer-grinder (Bajaj, India) was used to mash the grapes. The extracted juice (by use of juice squeezer) was sieved using a cheese cotton cloth and a mixture with a ratio of 1:1 $(v / v)$ of extracted juice and water was prepared. A hot plate was used to boil the mixture at $28 \pm 2{ }^{\circ} \mathrm{C}$ for a duration of 10-15 min and was immediately let to cool at room temperature. An inoculum consisting of L. plantarum (MTCC-1325) culture was inoculated to the grape juice and was made up in an incubator (Beautex Instruments, India) at $30{ }^{\circ} \mathrm{C}$ for $24 \mathrm{~h}$. This culture was used as a starter culture for conducting the proceeding experiments.

\section{Lactic acid fermentation of EFY}

EFY roots were finally washed for the elimination of the surface dirt and were grated/peeled and carefully chopped into small blocks/cubes (nearly $1 \times 1 \times 1 \mathrm{~cm}^{3}$ ). Blanching (cooking) of the cubes was conducted by incubation of these cubes in baking (boiling) water for 10-15 $\mathrm{min}$ at $70{ }^{\circ} \mathrm{C}$. Plastic jars $(500 \mathrm{~mL})$ (Polypet $\circledast$, Bombay, India) were used to dispense the blanched EFY cubes (140 g). Further, $300 \mathrm{~mL}$ of brine solution $(\mathrm{NaCl}, 2-10 \% \mathrm{w} / \mathrm{v})$ was added to each bottle. Three replicates/repeats were maintained for each salt concentration and the info from the biochemical analyses was determined as the mean of three repeats. Each bottle was inoculated with $10 \mathrm{~mL}$ of starter culture $\left(1 \times 10^{7} \mathrm{CFU} / \mathrm{mL}\right)$ lidded securely. The EFY brine solutions were incubated $\left(30 \pm 2{ }^{\circ} \mathrm{C}\right)$ and were left for fermentation process (42 days).

\section{Biochemical and proximate analysis}

Physical ( $\mathrm{pH}$ ) and biochemical, i.e., lactic acid (LA), titratable acidity (TA), starch, and total sugar constituents of EFY lactopickle were evaluated. A digital $\mathrm{pH}$ meter with the electrode (type-335, Systronic, India, Pvt. Ltd.) was used (standardized with a buffer solution of $\mathrm{pH} 7.0$ and 9.2) to determine the $\mathrm{pH}$ value of EFY lacto-pickle. TA was determined by the titration method (Amerine and Ough 1980) and an ultraviolet-visible spectrophotometer (Model Cecil CE-7250; Cecil Instruments Ltd., Cambridge, UK) was used to determine the contents of LA. The starch and total sugar (constituents) contents were detected (method described by Mahadevan and Sridhar 1998) and the data was revealed as the equivalent of grams per kilogram EFY lacto-pickle and grams per liter lacto-pickle brine solution.

The proximate compositions of EFY lacto-pickle, such as organic matter was measured by the procedure described in USDA (1984) and ash content was estimated by a muffle furnace method. The fat content (ether extract) was evaluated by continuous Soxhlet extraction (organic solvent like hexane) techniques (Socs Plus, SCS 4, Pelican Equipments, Chennai, Tamil Nadu, India), protein (nitrogen content, $\mathrm{N} \times 6.25$ ) content was determined by Kjeldahl digestion/method (Hoover 2001). Gross energy (kcal/g EFY lacto-pickle) was determined by using an adiabatic bomb calorimeter (Parr Instrument Company, Moline, IL, USA) (USDA 1984). Moisture was determined by vacuum oven (Lindberg/Blue $\mathrm{M}^{\mathrm{TM}}$ ), and crude fiber was evaluated according to the enzymatic-gravimetric method (Prosky et al. 1984) using Fibra Plus Fiber Tech apparatus (Pelican Equipments, T Nagar, Chennai, India). Protein, fat, and ash contents were reported as grams per kilogram EFY lacto-pickle. 


\section{Effect of shelf-life on cell viability and stability of EFY lacto-pickle}

EFY lacto-pickle $(75 \mathrm{~mL})$ formed after $72 \mathrm{~h}$ of fermentation were allowed to ferment (42 days) and preserved at room temperature for 6 months. Samples (EFY lacto-pickle for $8 \%$ equilibrated salt concentration) were taken at weekly intervals and counted from the Petri plates $(100 \mathrm{~mm} \times 18 \mathrm{~mm})$ containing MRS (Mann-Rogosa-Sharpe) agar medium (Tominaga and Sato 1996) and incubated $\left(30 \pm 2{ }^{\circ} \mathrm{C}\right)$ under microaerophilic (low oxygen) conditions for $24 \mathrm{~h}$. After incubation, colonies with distinct morphology were picked and subcultured individually. The viability of $L$. plantarum (MTCC-1325) culture and shelf-life of the EFY lacto-pickle was determined and expressed as colony-forming unit (CFU) per milliliter of lacto-pickle. The bacteria (other than LAB) was carried out by using Gram's staining method, colony appearance (sizes and shapes), and growing on nutrient agar. EFY lacto-pickle $(75 \mathrm{~mL}$ ) sample (in triplicates for enumeration of bacteria, fungi, and yeasts) was filtered by using a filtered disc $(0.45 \mu \mathrm{m})$ and a suction pump. The discs were plated on nutrient agar, potato dextrose agar (PDA), and wort agar plates for enumeration of bacteria, fungus, and yeasts, respectively (Dubey and Maheshwari 2004). The colonies formed on the agar plates (nutrient, PDA, wort) were then used to estimate the numbers of bacteria, fungus, and yeasts in the original sample. Colonies developing on plates from the last positive dilution $\left(10^{-1}\right.$ to $\left.10^{-6}\right)$ were first grouped by their macroscopic and microscopic morphotypes.

\section{Morphological (SEM) analysis}

The sample (EFY lacto-pickle) topography and interaction between L. plantarum (MTCC 1325) and EFY lacto-pickle was studied using scanning electron microscopy (SEM, JEOL, USA) according to a previously described method (Bernet et al. 1994) with some modifications. A drop of fermented EFY was fixed in $2.5 \%(v / v)$ glutaraldehyde in $0.1 \mathrm{M}$ phosphate buffer ( $\mathrm{pH} 7.2)$ for $24 \mathrm{~h}$ at room temperature. Following, the fixed EFY lacto-pickle were freeze-dried in a lyophilizer (Labconco, USA) and was taken on aluminum SEM pin stub/holder testing carbon conductive tape (doublesided adhesive) with an acceleration voltage of $10 \mathrm{kV}(50-\mu \mathrm{m}$ magnification) in low vacuum mode.

\section{Structural analysis of EFY lacto-pickle}

The bond level characterization of developed EFY lactopickle was recorded on an attenuated total reflectanceFourier transform infrared spectroscopy (ATR-FTIR) spectrophotometer (Alpha ATR-FTIR, Bruker, Germany). ATRFTIR was used for analysis of the bond variations between the fresh EFY (i.e., unfermented EFY) and the final product (i.e., lacto-pickle). The bond vibrations were measured by putting a sample with 128 scans and $2 / \mathrm{cm}$ resolution in the range of $4000-500 / \mathrm{cm}$ on the diamond crystal.

\section{GC-MS analysis}

Quantitative examination of the volatile compound profiles present in EFY lacto-pickle was determined using GC/MSQP 2010 SHIMADZU with flame ionization and mass spectrometry detection. The GC-MS system was fitted with VFNAX MAS capillary wax column $(L=30 \mathrm{~m}$ and $D=$ $0.25 \mathrm{~mm}$ ). Injection of the specimen into the column was enjoined with a carrier gas (He, $99.99 \%$ purity) at the flow/ drift rate of $1.5 \mathrm{~mL} / \mathrm{min}$. The commencing oven/kiln temperature was kept at $90{ }^{\circ} \mathrm{C}$ for 2 min with an increase of up to $220{ }^{\circ} \mathrm{C}$. The volatile organic compounds (VOCs) present in the sample (EFY lacto-pickle) were ionized at $70 \mathrm{eV}$ ionization energy, $230{ }^{\circ} \mathrm{C}$ ion source temperature and were analyzed over a mass electron $(\mathrm{m} / \mathrm{z})$ range $0-500$. The data collected in the form of chromatograms at changed retention time and corresponding mass spectra for different VOCs were plotted/ framed and compared against the spectral info/data with the NIST repository.

\section{Antioxidative property}

The 2,2-diphenyl-1-picryl-hydrazyl-hydrate (DPPH) free radical scavenging activity of EFY lacto-pickle was determined by spectrophotometric (UV-1800 spectrophotometer, Shimadzu, Japan) method (Marxen et al. 2007). The N, Ndimethyl-p-phenylenediamine (DMPD) assay was performed according to the method described by Fogliano et al. (1999) and ferric-reducing ability of plasma (FRAP) assay was performed as described by Benzie and Strain (1996).

\section{Sensory evaluation assay}

Sensory attributes of EFY lacto-pickle were assessed using a 5-point hedonic scale (wherein, maximum score/point, i.e., "five" fitted to "like extremely", and minimum score/point, i.e., "one" suited for "dislike extremely" and score " 0 " indicated as an in-consumable product). One hundred panelists (gender 43 women and 57 men; age group 30-45), chosen from the faculty, staff, and local inhabitants of many agronomical (botanical) departments who habitually consume pickles and other lactic-fermented commodities. Polypropylene transparent cups (tagged with 3-digit haphazard numbers) were used for serving the samples to the people. Provisions were made for questionnaires (public-opinion pull) and water for mouth rinsing within each tasting session. In order to familiarize panelists with the product, a session was conducted prior to evaluation in each step. To avoid any misinterpretation of the attributes, a thorough reading of the 
questionnaires and the gist of each attribute was recommended for the panelists. The sensory assessment score was identified as the mean of the panelists' count. The statistical significance of the variations checked among the scores of the two tests was evaluated using a standard $t$ test.

\section{Statistical methods}

The experimental data were subjected to evaluation of analytical and proximate results using factorial analysis of variance (ANOVA) through the general linear model (GLM) program. The Fischer's least significant difference (LSD) multiple testing/comparison test was used to correlate the determinant/factor level differences when significant (fitting) differences/deviation in ANOVA $(P<0.05)$ were observed. An $\alpha$-level was fixed a priori. The multivariate analysis (MVA), such as multiple variable (correlations) analysis and principal component analysis (PCA)/factor analysis was applied for scrutiny of the combined behavior of different variables. SPSS statistics (Windows 19.0, SPSS Inc., Chicago, IL, USA) were used for analysis of the data (input) design/matrix of the variables.

\section{Results and discussion}

In our previous work, we have standardized (RSM technique) the submerged fermentations (SmF) of EFY into Lacto-pickle using different fermentation specifications, i.e., salt concentration $(\mathrm{NaCl}, 2-10 \%, w / v)$, incubation period/duration (2-42 days), and inoculum capacity/ volume $(1-20 \%, v / v)$. However, $8 \%(w / v)$ salt concentration was found to be the most acceptable among all, in terms of organoleptic attributes. Moreover, $10 \%(v / v)$ inoculum volume (L. plantarum MTCC 1325) and 22 days of fermentation period found to be a maximum yield of fermented-/lacto-pickle (Behera et al. 2018). Lacto-pickles are usually made from the fresh ripened subtropical and tropical crops like mango, papaya, citrus, guava, and sapota, basically due to their high water and sugar content, suitable taste, flavor, and seasonal availability (Muniz et al. 2008). The analytical and proximate variations during the LA fermentation of EFY lacto-pickling development are reported afterward. In the present study, the mass of salt, if any, which might have opposed while expressing the quality of starch, LA, TA, etc., in grams per kilogram EFY lacto-pickle has been ignored. This is because, unlike surface and solid-state fermentation, $\mathrm{SmF}$ (in which the present study is conducted) does not tend to adhere or let much amount of salt to penetrate into the pickled surface and hence restrict alterations for the general trend of the data.

\section{Biochemical analysis}

The changes in acidity ( $\mathrm{pH}, \mathrm{TA}$, and LA) and carbohydrates (starch and total sugar) in the fermented product (cubes) during the course of fermentation are discussed below.

\section{Variations in $\mathrm{pH}$ during the EFY lacto-pickle fermentation}

$\mathrm{pH}$ plays an influential factor in the development of aroma and flavor of brewed/fermented vegetables and fruits (Liu 2003). It was observed that on the 7 th day of fermentation, there was a rapid decline in the $\mathrm{pH}$ (i.e., 6.4 on the 0 th day to 4.88 on 7 th day) (Table 1 ). The rapid decrease in $\mathrm{pH}$ might have occurred due to the presence of salt/brine solution and incubation time of fermentation. ANOVA result showed that the days of fermentation $(F(4,17)=127.34$, $P<0.001)$ and salt concentration $(F(5,17)=37.66$, $P<0.001)$ significantly affected the $\mathrm{pH}$. This finding corroborated with other similar fermented products, such as LA fermented cucumbers, Irish potato, table green olives, etc. (Ogunjobi et al. 2005). In the brew of togwa (a Tanzanian fermented cuisine) during the first $24 \mathrm{~h}$ of fermentation (carrying starter cultures of yeasts and LAB), the pH reported a drop from 5.87 to 3.24 (Mugula et al. 2003). Further, it has been reported that a quick drop in $\mathrm{pH}$ significantly affected the quality and texture of fermented products (Ogunjobi et al. 2005). The $\mathrm{pH}$ values were measured in time intervals of 7 days, (i.e., on 14th, 21st, 28th, $35 \mathrm{th}$, and $42 \mathrm{nd}$ ) of fermentation. However, there are no variations observed and the trends were found similar to the end of the pickling/fermentation process (42 days). Nevertheless, increasing the salt $(\mathrm{NaCl})$ concentrations $(0-10 \%, w / v)$ resulted in preventing the loss/decline in $\mathrm{pH}$, possibly due to less accumulation of LA. The "posthoc" analysis/tests also revealed that the salt concentration of $0-4 \%(w / v)$ did not differ significantly in comparison to other treatment means of salt concentrations $(6-10 \%, w / v)$ $(P<0.05$; LSD $)$. This was more evident after 21 days of fermentation at $8 \%(w / v)$ salt concentration. Most of the LAB were able to grow at acidic $\mathrm{pH}$ (optimum at 4.44.8 ) and, not surprisingly, were tolerant to $\mathrm{NaCl}$ concentrations within a range of 15 to $20 \mathrm{~g} / \mathrm{L}$ over the course of fermentation (Montet et al. 2006). Tolerating salts at higher concentrations is an advantageous property of LAB as this restricts the growth of non-desirable organisms and discourages proteolytic and pectinolytic enzyme activity, that is responsible for softening of vegetables. In our study, the strain L. plantarum (MTCC-1325) was able to tolerate up to $8-10 \%$ salt concentration which resulted in the comfortable EFY pickling process. However, earlier studies have reported higher salt tolerance capacities (up to $14 \%, w / v$ ) for this bacterium (Di Cagno et al. 2013). 
Table $1 \mathrm{pH}$ values of EFY lacto-pickle during LA fermentation

\begin{tabular}{|c|c|c|c|c|c|c|}
\hline Salt concentration $(\%)$ & 7 days & 14 days & 21 days & 28 days & 35 days & 42 days \\
\hline 0 & $4.88 \pm 0.13 b$ & $3.80 \pm 0.06 \mathrm{c}$ & $2.89 \pm 0.10 \mathrm{~b}$ & $2.78 \pm 0.10 \mathrm{~b}$ & $2.72 \pm 0.08 b$ & $2.70 \pm 0.09 \mathrm{c}$ \\
\hline 2 & $4.86 \pm 0.12 b$ & $3.76 \pm 0.06 b$ & $2.86 \pm 0.11 b$ & $2.76 \pm 0.10 \mathrm{c}$ & $2.76 \pm 0.10 \mathrm{c}$ & $2.69 \pm 0.08 \mathrm{c}$ \\
\hline 4 & $4.87 \pm 0.14 b$ & $3.77 \pm 0.08 \mathrm{c}$ & $2.82 \pm 0.09 b$ & $2.77 \pm 0.14 b$ & $2.67 \pm 0.12 b$ & $2.64 \pm 0.08 \mathrm{c}$ \\
\hline 6 & $4.82 \pm 0.13 b$ & $3.82 \pm 0.09 \mathrm{c}$ & $2.82 \pm 0.13 \mathrm{a}$ & $2.75 \pm 0.13 b$ & $2.72 \pm 0.11 b$ & $2.68 \pm 0.09 \mathrm{c}$ \\
\hline 8 & $4.83 \pm 0.13 b$ & $3.80 \pm 0.07 \mathrm{a}$ & $2.85 \pm 0.12 \mathrm{a}$ & $2.76 \pm 0.13 \mathrm{a}$ & $2.69 \pm 0.10 \mathrm{~b}$ & $2.67 \pm 0.10 \mathrm{c}$ \\
\hline 10 & $4.88 \pm 0.15 \mathrm{a}$ & $3.81 \pm 0.10 \mathrm{a}$ & $2.89 \pm 0.15 b$ & $2.78 \pm 0.15 \mathrm{a}$ & $2.68 \pm 0.13 a$ & $2.66 \pm 0.11 \mathrm{a}$ \\
\hline
\end{tabular}

Significant at $P<0.001$. Different letters in the same row indicate significant differences $(P<0.05 ; \mathrm{LSD})$

Initial ( 0 day) $\mathrm{pH}$ values of $\mathrm{EFY}$ cubes was $6.4 \pm \mathrm{SD}$

\section{Variations in TA during the EFY lacto-pickle fermentation}

Initial ( 0 day) titratable acidity of EFY cubes was $0.70 \mathrm{~g} / \mathrm{kg}$ and for brine, it was observed to be considerably low (i.e., $0.18 \mathrm{~g} / \mathrm{L}$ ). However, throughout the passage of fermentation (0-42 days), the variations were significant (Table 2). Interestingly, the rise in TA production showed an inversely proportional relationship to the increase in $\mathrm{NaCl}$ concentration in the brine solution. ANOVA analysis of cube samples showed the factors, such as the salt content and fermentation time significantly affected the TA levels, i.e., $(F(5,17)=$ $270.64, P<0.001)$ and $(F(4,17)=187.49, P<0.001)$. Similar results were obtained for saline/brine samples, i.e., TA was significantly affected with differences in salt concentration $(F(5,17)=210.66, P<0.001)$. It seems that an increase of TA in brine is probably due to an appreciable quantity of organic acid, which might have seeped out of the EFY onto brine, mostly because of higher osmotic pressure generated by the salt concentration (Panda and Ray 2007).

\section{Variations in LA during the EFY lacto-pickle fermentation}

Lactic fermentation by Lactobacilli mostly produces LA as the prime and essential organic acid (Gardner et al. 2001). In the present study, L. plantarum (MTCC-1325) was used as a starter culture, to harvest predominately L (+) LA (Liu 2003). Initial observations revealed nearly fewer amounts of LA were found in EFY blocks $/$ cubes $(0.50 \mathrm{~g} / \mathrm{kg})$ and in a saline/brine solution $(0 \mathrm{~g} / \mathrm{L})$. However, a significant increase in LA concentration $(1.3-3.5 \mathrm{~g} / \mathrm{kg})$ in the fermentation medium was observed after 7 days of inoculation of $L$. plantarum (Table 3). The sharp increase in the LA concentration might have been owing to the transformation of fermentable sugars into LA by the sportive action of L. plantarum (Di Cagno et al. 2013). Further, the results also confirmed a reduction of LA concentration in EFY pickles as compared to brine. Hence, it is supposed that the lion's share of salt supplement, resided in brine while a small amount penetrated into EFY lacto-pickles. Further, this might have led to a change in osmotic pressure
Table 2 Titratable acidity (TA) concentration of EFY lactopickles $(\mathrm{g} / \mathrm{kg}$ cubes) and brine $(\mathrm{g} / \mathrm{L})$ during fermentation

\begin{tabular}{lllllll}
\hline $\begin{array}{l}\text { Salt concentration } \\
(\%)\end{array}$ & 7 days & 14 days & 21 days & 28 days & 35 days & 42 days \\
\hline 0 & & & & & & \\
& $5.2 \pm 0.4 \mathrm{~b}$ & $5.4 \pm 0.3 \mathrm{~b}$ & $5.6 \pm 0.3 \mathrm{c}$ & $5.0 \pm 0.2 \mathrm{c}$ & $4.1 \pm 0.2 \mathrm{~b}$ & $3.8 \pm 0.3 \mathrm{~b}$ \\
2 & $(5.4 \pm 0.3) \mathrm{c}$ & $(5.5 \pm 0.4) \mathrm{c}$ & $(5.9 \pm 0.1) \mathrm{b}$ & $(6.2 \pm 0.3) \mathrm{c}$ & $(4.7 \pm 0.3) \mathrm{c}$ & $(4.4 \pm 0.3) \mathrm{c}$ \\
& $4.8 \pm 0.3 \mathrm{c}$ & $4.9 \pm 0.3 \mathrm{~b}$ & $5.3 \pm 0.1 \mathrm{~b}$ & $4.8 \pm 0.2 \mathrm{~b}$ & $3.9 \pm 0.4 \mathrm{c}$ & $3.6 \pm 0.2 \mathrm{~b}$ \\
4 & $(5.0 \pm 0.1) \mathrm{c}$ & $(5.5 \pm 0.3) \mathrm{b}$ & $(5.8 \pm 0.1) \mathrm{b}$ & $(5.5 \pm 0.3) \mathrm{b}$ & $(4.4 \pm 0.2) \mathrm{c}$ & $(4.2 \pm 0.3) \mathrm{b}$ \\
& $4.0 \pm 0.4 \mathrm{~b}$ & $4.3 \pm 0.2 \mathrm{a}$ & $5.1 \pm 0.1 \mathrm{~b}$ & $4.5 \pm 0.4 \mathrm{c}$ & $3.6 \pm 0.2 \mathrm{~b}$ & $3.2 \pm 0.3 \mathrm{~b}$ \\
6 & $(4.3 \pm 0.1) \mathrm{b}$ & $(4.8 \pm 0.3) \mathrm{a}$ & $(5.4 \pm 0.2) \mathrm{b}$ & $(5.0 \pm 0.3) \mathrm{a}$ & $(4.0 \pm 0.3) \mathrm{b}$ & $(3.6 \pm 0.2) \mathrm{b}$ \\
& $3.8 \pm 0.3 \mathrm{~b}$ & $3.9 \pm 0.1 \mathrm{~b}$ & $4.5 \pm 0.2 \mathrm{~b}$ & $4.2 \pm 0.3 \mathrm{a}$ & $3.2 \pm 0.3 \mathrm{~b}$ & $2.9 \pm 0.1 \mathrm{~b}$ \\
& $(4.1 \pm 0.3) \mathrm{b}$ & $(4.3 \pm 0.3) \mathrm{b}$ & $(4.9 \pm 0.3) \mathrm{a}$ & $(4.8 \pm 0.3) \mathrm{b}$ & $(3.8 \pm 0.1) \mathrm{b}$ & $(3.2 \pm 0.2) \mathrm{b}$ \\
& $3.4 \pm 0.2 \mathrm{a}$ & $3.7 \pm 0.1 \mathrm{a}$ & $3.9 \pm 0.3 \mathrm{c}$ & $3.5 \pm 0.1 \mathrm{c}$ & $2.7 \pm 0.4 \mathrm{a}$ & $2.6 \pm 0.3 \mathrm{c}$ \\
10 & $(3.9 \pm 0.2) \mathrm{a}$ & $(4.1 \pm 0.2) \mathrm{a}$ & $(4.9 \pm 0.2) \mathrm{a}$ & $(4.5 \pm 0.2) \mathrm{a}$ & $(3.2 \pm 0.2) \mathrm{a}$ & $(2.8 \pm 0.1) \mathrm{c}$ \\
& $0.9 \pm 0.2 \mathrm{a}$ & $1.7 \pm 0.1 \mathrm{a}$ & $3.3 \pm 0.3 \mathrm{a}$ & $3.0 \pm 0.1 \mathrm{a}$ & $2.6 \pm 0.2 \mathrm{a}$ & $1.9 \pm 0.3 \mathrm{a}$ \\
& $(1.1 \pm 0.1) \mathrm{b}$ & $(1.9 \pm 0.1) \mathrm{a}$ & $(3.7 \pm 0.1) \mathrm{b}$ & $(3.4 \pm 0.3) \mathrm{b}$ & $(2.9 \pm 0.3) \mathrm{b}$ & $(2.2 \pm 0.3) \mathrm{b}$ \\
\hline
\end{tabular}

Significant at $P<0.001$. Different letters in the same row indicate significant differences $(P<0.05 ; \mathrm{LSD})$ Initial ( 0 day) titratable acidity of EFY cubes was $0.70 \mathrm{~g} / \mathrm{kg}$ and for brine was $0.18 \mathrm{~g} / \mathrm{L}$

Figures in parentheses indicate the corresponding values for lacto-pickle in brine $\pm \mathrm{SD}$ 
within cubes and brine elicit the extraction/loss of a considerable volume of LA from cubes into the brine to retain equilibrium in fermentation medium (Montet et al. 2006). Experimental results further revealed that the LA concentration was significantly more in cubes treated with $0 \%$ and $2 \%$ $\mathrm{NaCl}$ as compared to those treated with high $(8-10 \%)$ salt concentrations. A possible explanation for this might be the increased salt concentrations could repress the growth of L. plantarum (Zhang et al. 2000; Montet et al. 2006). ANOVA analysis showed that the salt concentration $(F$ (5, $17)=66.78, P<0.001]$ and frothing/fermentation period $(F$ $(4,17)=269.88, P<0.001)$ had significantly affected the production of LA in EFY lacto-pickle in brine samples. Further, the post hoc tests confirmed, that means of both 8 and $10 \%$ salt concentrations $(w / v)$ and days of fermentation significantly varied, in respect to LA production; however, $8 \%(w / v)$ salt concentration varied most significantly $(P<0.05$; LSD).

\section{Variations in starch during the EFY lacto-pickle fermentation}

EFY roots are rich in starch, which serves as a nutrient source for amylolytic organisms (organisms converting starch into sugar/saccharose) (Sharma and Satyanarayana 2013). Strains of L. plantarum (LMG-18053, NCIM-2084, MTCC-1407, and MTCC-1325) have been made known to be amylolytic (Reddy et al. 2008) and hence, in the present study, variations in starch content after inoculation of L. plantarum (MTCC$1325)$ is studied. The experimental results showed a marginal decrease in the starch content $(148 \mathrm{~g} / \mathrm{kg}$ in 0 days to 145.0 $135.0 \mathrm{~g} / \mathrm{kg}$ ) in the fermented EFY lacto-pickle after 7 days of fermentation in EFY cubes (Table 4). Further, with different salt concentrations in the brine and with an increase in fermentation time (42 days), a steep decrease of starch content (94.7$68.0 \mathrm{~g} / \mathrm{kg}$ ) in the EFY lacto-pickle was observed. This reduction in starch content is attributed to the amylolytic response of L. plantarum (MTCC-1325) that utilized the starch in the EFY lacto-pickle. However, during fermentation, the starch content in brine was found less as compared to EFY lactopickle. A rational reason for this might be the ability of the starch to dissolve into organic acids as compared to cold water. Panda and Ray (2007) reported that the $\alpha$-amylase activity of L. plantarum (MTCC-1407) was responsible for the conversion of starch into sugar in preparation of sweet-potato lacto-pickle. ANOVA analysis showed that the incubation time of fermentation, $(F(4,17)=1534.68, P<0.001)$ and salt concentration, $(F(5,17)=638.44, P<0.001)$ was significantly affected by starch contents in EFY lacto-pickle of brine samples. Moreover, the post hoc tests/analysis showed that salt concentrations of $8 \%$ and $10 \%$ had significantly affected the days $(0,7,14$, and 21$)$ of fermentation; however, $8 \%$ salt concentration varied significantly in terms of variation of starch in EFY lacto-pickle $(P<0.001 ;$ LSD).

\section{Variations in total sugar}

The variations observed in the total sugar content about the fermented EFY lacto-pickle were analogous to that of starch as represented in "Variations in starch during the EFY lactopickle fermentation" section. With the rise in the incubation time of fermentation, (i.e., from 7 to 42 days), sugar concentration continually decreased (Table 5). It was apparent that the amylolytic behavior of the inoculant microorganisms

Table 3 Lactic acid (LA) concentration of EFY lacto-pickles ( $\mathrm{g} / \mathrm{kg}$ cubes) and brine $(\mathrm{g} / \mathrm{L})$ during fermentation

\begin{tabular}{|c|c|c|c|c|c|c|}
\hline Salt concentration $(\%)$ & 7 days & 14 days & 21 days & 28 days & 35 days & 42 days \\
\hline \multirow[t]{2}{*}{0} & $3.5 \pm 0.2 \mathrm{a}$ & $3.9 \pm 0.1 \mathrm{a}$ & $4.2 \pm 0.2 b$ & $3.8 \pm 0.3 b$ & $3.2 \pm 0.1 \mathrm{c}$ & $3.1 \pm 0.3 \mathrm{c}$ \\
\hline & $(4.1 \pm 0.1) \mathrm{b}$ & $(5.3 \pm 0.3) \mathrm{b}$ & $(5.2 \pm 0.3) \mathrm{b}$ & $(5.0 \pm 0.2) \mathrm{b}$ & $(4.8 \pm 0.2) \mathrm{c}$ & $(4.5 \pm 0.3) \mathrm{c}$ \\
\hline \multirow[t]{2}{*}{2} & $2.8 \pm 0.3 b$ & $3.7 \pm 0.1 \mathrm{a}$ & $4.0 \pm 0.2 b$ & $3.4 \pm 0.2 b$ & $3.0 \pm 0.3 \mathrm{c}$ & $2.6 \pm 0.3 \mathrm{c}$ \\
\hline & $(3.9 \pm 0.1) \mathrm{b}$ & $(5.1 \pm 0.2) \mathrm{c}$ & $(5.1 \pm 0.2) \mathrm{a}$ & $(4.5 \pm 0.2) \mathrm{c}$ & $(4.3 \pm 0.2) \mathrm{c}$ & $(4.0 \pm 0.2) \mathrm{c}$ \\
\hline \multirow[t]{2}{*}{4} & $2.6 \pm 0.2 b$ & $3.3 \pm 0.3 \mathrm{a}$ & $3.8 \pm 0.2 \mathrm{a}$ & $3.3 \pm 0.2 b$ & $2.8 \pm 0.2 \mathrm{c}$ & $2.2 \pm 0.1 \mathrm{c}$ \\
\hline & $(3.3 \pm 0.1) \mathrm{b}$ & $(4.3 \pm 0.2) b$ & $(5.0 \pm 0.1) \mathrm{a}$ & $(4.0 \pm 0.3) \mathrm{c}$ & $(4.0 \pm 0.3) \mathrm{c}$ & $(3.6 \pm 0.3) \mathrm{c}$ \\
\hline \multirow[t]{2}{*}{6} & $2.0 \pm 0.1 \mathrm{~b}$ & $2.5 \pm 0.3 \mathrm{a}$ & $3.5 \pm 0.2 b$ & $3.2 \pm 0.2 b$ & $2.4 \pm 0.1 b$ & $1.9 \pm 0.2 \mathrm{c}$ \\
\hline & $(3.0 \pm 0.2) \mathrm{c}$ & $(3.8 \pm 0.2) \mathrm{b}$ & $(4.7 \pm 0.3) b$ & $(3.8 \pm 0.3) \mathrm{c}$ & $(3.7 \pm 0.2) \mathrm{c}$ & $(3.3 \pm 0.1) \mathrm{c}$ \\
\hline \multirow[t]{2}{*}{8} & $1.6 \pm 0.2 \mathrm{a}$ & $1.7 \pm 0.2 \mathrm{a}$ & $3.0 \pm 0.2 b$ & $2.5 \pm 0.2 b$ & $2.0 \pm 0.4 \mathrm{~b}$ & $1.6 \pm 0.2 b$ \\
\hline & $(2.8 \pm 0.2) \mathrm{a}$ & $(3.3 \pm 0.4) \mathrm{a}$ & $(4.3 \pm 0.3) \mathrm{a}$ & $(3.5 \pm 0.1) \mathrm{a}$ & $(3.2 \pm 0.2) \mathrm{c}$ & $(2.7 \pm 0.2) \mathrm{c}$ \\
\hline \multirow[t]{2}{*}{10} & $1.3 \pm 0.2 \mathrm{a}$ & $1.9 \pm 0.1 \mathrm{a}$ & $2.8 \pm 0.2 \mathrm{a}$ & $2.0 \pm 0.2 \mathrm{a}$ & $1.6 \pm 0.2 b$ & $1.3 \pm 0.3 b$ \\
\hline & $(1.6 \pm 0.1) \mathrm{a}$ & $(2.7 \pm 0.2) \mathrm{a}$ & $(3.9 \pm 0.2) \mathrm{a}$ & $(3.0 \pm 0.3) b$ & $(2.6 \pm 0.3) b$ & $(2.3 \pm 0.2) \mathrm{b}$ \\
\hline
\end{tabular}

Significant at $P<0.001$. Different letters in the same row indicate significant differences $(P<0.05 ;$ LSD $)$

Initial ( 0 day) LA of EFY cubes was $0.50 \mathrm{~g} / \mathrm{kg}$ and for brine was $0 \mathrm{~g} / \mathrm{L}$.

Figures in parentheses indicate the corresponding values for lacto-pickle in brine $\pm \mathrm{SD}$ 
Table 4 The starch concentration of EFY lacto-pickles ( $\mathrm{g} / \mathrm{kg}$ cubes) and brine $(\mathrm{g} / \mathrm{L})$ during fermentation

\begin{tabular}{|c|c|c|c|c|c|c|}
\hline Salt concentration (\%) & 7 days & 14 days & 21 days & 28 days & 35 days & 42 days \\
\hline \multirow[t]{2}{*}{0} & $145.0 \pm 6.4^{\mathrm{c}}$ & $138.8 \pm 4.6^{\mathrm{b}}$ & $130.7 \pm 4.2^{\mathrm{c}}$ & $118.7 \pm 4.0^{\mathrm{c}}$ & $108.3 \pm 3.7^{\mathrm{c}}$ & $94.7 \pm 3.2^{\mathrm{c}}$ \\
\hline & $(24.2 \pm 0.3)^{\mathrm{c}}$ & $(22.4 \pm 0.1)^{\mathrm{b}}$ & $(18.0 \pm 0.1)^{\mathrm{b}}$ & $(15.3 \pm 0.3)^{\mathrm{c}}$ & $(12.8 \pm 0.2)^{\mathrm{b}}$ & $(12.0 \pm 0.2)^{\mathrm{b}}$ \\
\hline \multirow[t]{2}{*}{2} & $143.4 \pm 5.8^{\mathrm{c}}$ & $133.2 \pm 3.8^{\mathrm{b}}$ & $128.2 \pm 4.7^{b}$ & $115.5 \pm 3.5^{\mathrm{b}}$ & $103.4 \pm 3.8^{\mathrm{c}}$ & $83.1 \pm 3.9^{\mathrm{c}}$ \\
\hline & $(21.3 \pm 0.5)^{\mathrm{c}}$ & $(17.2 \pm 0.3)^{\mathrm{b}}$ & $(15.6 \pm 0.3)^{\mathrm{b}}$ & $(13.2 \pm 0.6)^{\mathrm{b}}$ & $(11.3 \pm 0.4)^{\mathrm{c}}$ & $(10.6 \pm 0.3)^{\mathrm{c}}$ \\
\hline \multirow[t]{2}{*}{4} & $141.3 \pm 6.6^{\mathrm{b}}$ & $132.7 \pm 5.3^{b}$ & $118.4 \pm 5.6^{\mathrm{b}}$ & $102.6 \pm 3.3^{b}$ & $100.2 \pm 4.4^{\mathrm{b}}$ & $70.3 \pm 5.3^{\mathrm{c}}$ \\
\hline & $(18.2 \pm 0.4)^{\mathrm{b}}$ & $(15.5 \pm 0.5)^{\mathrm{c}}$ & $(13.3 \pm 0.2)^{\mathrm{c}}$ & $(12.0 \pm 0.4)^{\mathrm{c}}$ & $(9.4 \pm 0.5)^{\mathrm{c}}$ & $(10.0 \pm 0.5)^{b}$ \\
\hline \multirow[t]{2}{*}{6} & $141.0 \pm 5.4^{\mathrm{b}}$ & $130.0 \pm 5.0^{\mathrm{b}}$ & $116.7 \pm 4.7^{\mathrm{c}}$ & $100.3 \pm 5.0^{b}$ & $92.5 \pm 3.9^{\mathrm{c}}$ & $69.7 \pm 4.0^{\mathrm{b}}$ \\
\hline & $(15.7 \pm 0.2)^{\mathrm{b}}$ & $(13.3 \pm 0.4)^{\mathrm{b}}$ & $(12.0 \pm 0.6)^{\mathrm{c}}$ & $(10.6 \pm 0.3)^{\mathrm{b}}$ & $(8.6 \pm 0.4)^{\mathrm{c}}$ & $(9.2 \pm 0.3)^{\mathrm{b}}$ \\
\hline \multirow[t]{2}{*}{8} & $139.0 \pm 2.6^{\mathrm{a}}$ & $124.0 \pm 2.3^{\mathrm{a}}$ & $112.0 \pm 2.7^{\mathrm{c}}$ & $98.0 \pm 1.9^{\mathrm{a}}$ & $84.0 \pm 2.0^{\mathrm{a}}$ & $55.0 \pm 2.8^{\mathrm{a}}$ \\
\hline & $(14.9 \pm 0.3)^{\mathrm{a}}$ & $(12.0 \pm 0.5)^{\mathrm{a}}$ & $(10.3 \pm 0.5)^{\mathrm{a}}$ & $(8.5 \pm 0.4)^{\mathrm{a}}$ & $(7.3 \pm 0.4)^{\mathrm{a}}$ & $(8.8 \pm 0.3)^{\mathrm{a}}$ \\
\hline \multirow[t]{2}{*}{10} & $135.0 \pm 2.0^{\mathrm{a}}$ & $120.0 \pm 2.9^{\mathrm{a}}$ & $117.0 \pm 2.1^{\mathrm{c}}$ & $108.0 \pm 2.7^{\mathrm{a}}$ & $91.0 \pm 2.2^{\mathrm{a}}$ & $68.0 \pm 2.3^{\mathrm{a}}$ \\
\hline & $(12.6 \pm 0.6)^{\mathrm{a}}$ & $(10.2 \pm 0.3)^{\mathrm{a}}$ & $(8.4 \pm 0.4)^{\mathrm{a}}$ & $(7.0 \pm 0.6)^{\mathrm{a}}$ & $(6.2 \pm 0.3)^{\mathrm{a}}$ & $(8.4 \pm 0.2)^{\mathrm{a}}$ \\
\hline
\end{tabular}

*Significant at $P<0.001$. Different letters in the same row indicate significant differences $(P<0.05$; LSD)

Initial ( 0 day) starch of EFY cubes was $148 \pm 2.1 \mathrm{~g} / \mathrm{Kg}$ and for brine was $0 \mathrm{~g} / \mathrm{L}$.

*Figures in parentheses indicate the corresponding values for Lacto-pickle in brine

$\pm \mathrm{SD}$

(L. plantarum MTCC-1325), was the responsible factor which ultimately led to LA during organic acid metabolism. Similar observations were stated by Joshi and Somesh (2010) while fermentation of vegetables (radish, carrot, and cucumber) using L. plantarum (NCDC-020) as a starter. However, in the present study, the total amount of fermentable sugar generated during the fermentation process was not converted into LA. This might have resulted because of the intake of some fraction of sugars for the metabolic process of the inoculum (L. plantarum) (Montet et al. 2006). ANOVA results for $\mathrm{NaCl}$ concentration and days of fermentation for brine samples showed significant differences, i.e., $(F(5,17)=667.48$,
$P<0.001)$, and $(F(4,17)=355.821, P<0.001)$ in terms of variation in total sugar contents in EFY lacto-pickle. Post hoc analysis showed the days of fermentation (i.e., 7, 14, and 21) and both brine samples ( $8 \%$ and $10 \%$ ) had a significant effect on the variation of total sugar content; however, $8 \%$ brine solution varied most significantly with respect to variation of total sugar content in EFY lacto-pickle $(P<0.001 ; \mathrm{LSD})$.

\section{Proximate analysis}

From the preliminary experimental results, it was evident that EFY lacto-pickle with $8 \%$ brine solutions was acceptable both
Table 5 Total sugar concentration of EFY Lactopickles $(\mathrm{g} / \mathrm{Kg}$ cubes) and brine* $(\mathrm{g} / \mathrm{L})$ during fermentation

\begin{tabular}{lllllll}
\hline $\begin{array}{l}\text { Salt concentration } \\
(\%)\end{array}$ & 7 days & 14 days & 21 days & 28 days & 35 days & 42 days \\
\hline 0 & & & & & & \\
& $12.0 \pm 2.8 \mathrm{~b}$ & $11.8 \pm 2.3 \mathrm{a}$ & $10.2 \pm 2.2 \mathrm{a}$ & $8.0 \pm 1.2 \mathrm{c}$ & $6.6 \pm 0.7 \mathrm{a}$ & $5.3 \pm 0.2 \mathrm{c}$ \\
2 & $(9.5 \pm 2.2) \mathrm{b}$ & $(8.3 \pm 0.2) \mathrm{a}$ & $(7.0 \pm 0.2) \mathrm{a}$ & $(6.0 \pm 0.1) \mathrm{a}$ & $(5.6 \pm 0.4) \mathrm{a}$ & $(4.0 \pm 0.3) \mathrm{c}$ \\
& $11.6 \pm 2.0 \mathrm{c}$ & $11.3 \pm 1.1 \mathrm{~b}$ & $10.0 \pm 0.8 \mathrm{a}$ & $7.8 \pm 0.2 \mathrm{~b}$ & $5.8 \pm 0.6 \mathrm{~b}$ & $4.1 . \pm 0.3 \mathrm{~b}$ \\
4 & $(10.0 \pm 1.2) \mathrm{b}$ & $(9.4 \pm 0.9) \mathrm{b}$ & $(8.5 \pm 0.9) \mathrm{a}$ & $(7.3 \pm 0.1) \mathrm{a}$ & $(5.2 \pm 0.2) \mathrm{b}$ & $(3.8 \pm 0.1) \mathrm{b}$ \\
& $11.1 \pm 1.4 \mathrm{~b}$ & $11.0 \pm 1.3 \mathrm{c}$ & $9.2 \pm 0.2 \mathrm{a}$ & $6.7 \pm 0.3 \mathrm{c}$ & $4.6 \pm 0.5 \mathrm{~b}$ & $3.0 \pm 0.2 \mathrm{c}$ \\
6 & $(10.2 \pm 0.8) \mathrm{c}$ & $(9.0 \pm 0.7) \mathrm{c}$ & $(8.0 \pm 0.5) \mathrm{c}$ & $(6.0 \pm 0.8) \mathrm{a}$ & $(3.5 \pm 0.2) \mathrm{c}$ & $(2.2 \pm 0.3) \mathrm{c}$ \\
& $10.9 \pm 1.2 \mathrm{~b}$ & $10.4 \pm 0.6 \mathrm{~b}$ & $8.9 \pm 0.6 \mathrm{~b}$ & $5.3 \pm 0.2 \mathrm{a}$ & $3.3 \pm 0.4 \mathrm{a}$ & $2.6 \pm 0.3 \mathrm{a}$ \\
& $(8.9 \pm 0.3) \mathrm{b}$ & $(7.7 \pm 0.4) \mathrm{a}$ & $(6.8 \pm 0.5) \mathrm{a}$ & $(4.0 \pm 0.3) \mathrm{b}$ & $(3.0 \pm 0.1) \mathrm{a}$ & $(1.8 \pm 0.1) \mathrm{b}$ \\
& $10.8 \pm 0.4 \mathrm{a}$ & $8.3 \pm 0.5 \mathrm{a}$ & $6.4 \pm 0.3 \mathrm{a}$ & $4.1 \pm 0.2 \mathrm{a}$ & $2.5 \pm 0.3 \mathrm{a}$ & $1.3 \pm 0.1 \mathrm{a}$ \\
10 & $(8.5 \pm 0.3) \mathrm{a}$ & $(6.3 \pm 0.2) \mathrm{a}$ & $(4.8 \pm 0.4) \mathrm{a}$ & $(3.6 \pm 0.1) \mathrm{a}$ & $2.0 \pm 0.3) \mathrm{a}$ & $1.7 \pm 0.3) \mathrm{a}$ \\
& $9.2 \pm 0.2 \mathrm{a}$ & $6.6 \pm 0.2 \mathrm{a}$ & $4.8 \pm 0.1 \mathrm{~b}$ & $3.1 \pm 0.1 \mathrm{a}$ & $2.5 \pm 0.2 \mathrm{a}$ & $1.6 \pm 0.1 \mathrm{~b}$ \\
& $(6.9 \pm 0.1) \mathrm{a}$ & $(5.7 \pm 0.3) \mathrm{b}$ & $3.5 \pm 0.2) \mathrm{b}$ & $2.8 \pm 0.1) \mathrm{a}$ & $(1.9 \pm 0.2) \mathrm{a}$ & $1.5 \pm 0.1) \mathrm{a}$ \\
\hline
\end{tabular}

Significant at $P<0.001$. Different letters in the same row indicate significant differences $(P<0.05 ; \mathrm{LSD})$ Initial (0 day) total sugar of EFY cubes was $12.8 \pm 0.6 \mathrm{~g} / \mathrm{kg}$ and for brine was $0 \mathrm{~g} / \mathrm{L}$.

Figures in parentheses indicate the corresponding values for lacto-pickle in brine $\pm \mathrm{SD}$ 
organoleptically and taste-wise. Hence, proceeding experiment was conducted with EFY fermented with saline/brine of the above mentioned $(8 \%, w / v) \mathrm{NaCl}$ concentrations. The relative/proximate proportion of EFY lacto-pickle is depicted in Table 6. With increase in fermentation time, subsequent decrease in ash, protein, and organic loads were observed, with no significant alterations in calorific value and fat content. The obtained results were in agreement to Ogunjobi et al. (2005) who proclaimed decrease in ash quantity (8.01 to $4.08 \mathrm{mg} / \mathrm{g}$ ) of Irish potato (Solanum tuberosum) in brine solution $(2 \%)$ during spontaneous fermentation process. The decline in total sugar (carbohydrate content) is an additional choice/advantage, more specifically, for diabetic patients (Arva et al. 2013). ANOVA results showed that all periods of fermentation, (i.e., from 0 to 21 days) had significant result on $8 \%$ the salt concentration. For example, organic matter $(F$ $(6,14)=623.06, P<0.05)$; ash $(F(6,14)=384.33, P<0.05)$; fat $(F(6,14)=208.4, P<0.05)$; crude protein $(F(6,14)=$ $256.22, P<0.05)$; etc. Further, ANOVA reveals that there was no significant effect of incubation time during the fermentation on the gross energy, $(F(6,14)=3.25, P<0.032)$.

\section{Effect of shelf-life on cell viability and stability of EFY lacto-pickle}

Microscopic observation revealed that the starter culture (L. plantarum MTCC-1325) were Gram-positive and long slender rod-shaped bacillus. The L. plantarum (MTCC$1325)$ counts at 7 days of fermentation $(\mathrm{NaCl}, 8 \%, w / v)$ was in the range of $1.4 \times 10^{7} \mathrm{CFU} / \mathrm{mL}$ which decreased $\left(0.8 \times 10^{7} \mathrm{CFU} / \mathrm{mL}\right)$ up to 42 days of fermentation (Table 7). Following it, a static phase was observed during 6 months of storage. Lactobacillus plantarum (MTCC-1325) are known to readily grow on food substrates with lower $\mathrm{pH}$, even up to a point where other competing organisms strive to sustain. Reasonably, at higher salt concentrations $(8 \%, w / v)$, the growth and activity of other microbes (except salt-tolerant strains of L. plantarum (MTCC-1325) (Sivakumar et al. 2010) might have been inhibited. Further, the quality and taste of EFY lacto-pickle was stable for 6 months without any deterioration. Enumeration of fungus and yeast cells in the EFY lacto-pickle by potato dextrose agar (PDA) and wort agar plates showed the presence of 1-2 CFU/75 mL of EFY lacto-pickle, which was negligible. No other microorganisms were detected in the EFY lacto-pickle samples which ensured its sterility.

\section{Morphological characteristics}

The morphology and adhesion of L. plantarum (MTCC-1325) on EFY lacto-pickle was observed by SEM image. This observation is similar to those of other workers who have studied interactions of Lactobacillus and fermented roots and tubers (Wang et al. 2010). SEM was conducted at $10 \mathrm{kV}$ to visualize the cross section and attachment of L. plantarum (MTCC1325) to fermented EFY lacto pickle. The photograph shows the strong attachment of rod-shaped L. plantarum (MTCC1325 ) to the surface of EFY pickle (Fig. 1). This is the evidence of fermented EFY as a carrier of benevolent microbial strain along with the inherent nutritional properties of EFY.

\section{Structural analysis of EFY lacto-pickle}

The infrared spectra used to detect the vibrational frequencies/ bond length between the atoms of study samples. The spectra $(4000-500 / \mathrm{cm})$ were inferred by using the guidelines of

Table 6 Proximate composition of EFY Lacto-pickles during LA fermentation

\begin{tabular}{|c|c|c|c|c|c|c|c|c|}
\hline $\begin{array}{l}\text { Equilibrated salt } \\
\text { concentration }(\%)\end{array}$ & Days & $\begin{array}{l}\text { Organic matter } \\
(\mathrm{g} / \mathrm{kg})\end{array}$ & Ash (g/kg) & Fat $(\mathrm{g} / \mathrm{kg})$ & $\begin{array}{l}\text { Crude protein } \\
(\mathrm{g} / \mathrm{kg})\end{array}$ & $\begin{array}{l}\text { Gross fiber energy } \\
(\mathrm{kCal} / \mathrm{g})\end{array}$ & $\begin{array}{l}\text { Moisture } \\
(\%)\end{array}$ & $\begin{array}{l}\text { Dietary } \\
(\mathrm{g} / \mathrm{kg})\end{array}$ \\
\hline \multirow[t]{7}{*}{8} & 0 & $208.7 \pm 11.3 b$ & $839.80 \pm 38.5 c$ & $32.7 \pm 0.3 b$ & $52.7 \pm 0.6 \mathrm{a}$ & $\begin{array}{c}4.2 \pm 10.8 \mathrm{~b} \\
18.9 \pm 3.1 \mathrm{a}\end{array}$ & $75.5 \pm 4.8 \mathrm{~b}$ & \\
\hline & 7 & $204.4 \pm 15.5 b$ & $815.0 \pm 33.5 \mathrm{c}$ & $30.8 \pm 0.2 b$ & $49.8 \pm 0.3 \mathrm{a}$ & $\begin{array}{l}3.08 \pm 0.7 \mathrm{~b} \\
18.5 \pm 2.9 \mathrm{a}\end{array}$ & $75.5 \pm 4.8 b$ & \\
\hline & 14 & $201.0 \pm 10.5 \mathrm{a}$ & $794.0 \pm 27.5 c$ & $29.3 \pm 0.5 \mathrm{a}$ & $47.3 \pm 0.3 \mathrm{a}$ & $\begin{array}{l}3.07 \pm 0.7 \mathrm{~b} \\
17.6 \pm 2.0 \mathrm{a}\end{array}$ & $74.6 \pm 4.7 \mathrm{a}$ & \\
\hline & 21 & $185.5 \pm 18.5 \mathrm{a}$ & $766.0 \pm 19.0 \mathrm{~b}$ & $28.6 \pm 0.1 \mathrm{a}$ & $45.6 \pm 0.1 b$ & $\begin{array}{c}3.05 \pm 0.5 \mathrm{a} \\
17.2 \pm 1.8 \mathrm{a}\end{array}$ & $72.2 \pm 4.2 \mathrm{a}$ & \\
\hline & 28 & $183.0 \pm 17.6 \mathrm{a}$ & $630.0 \pm 13.0 \mathrm{c}$ & $25.2 \pm 0.1 \mathrm{a}$ & $44.2 \pm 0.2 b$ & $\begin{array}{l}3.00 \pm 0.5 \mathrm{a} \\
16.8 \pm 1.5 \mathrm{~b}\end{array}$ & $68.0 \pm 3.4 \mathrm{a}$ & \\
\hline & 35 & $179.5 \pm 20.0 \mathrm{~b}$ & $602.9 \pm 11.5 b$ & $23.7 \pm 0.2 \mathrm{a}$ & $40.7 \pm 0.3 b$ & $\begin{array}{l}2.78 \pm 0.5 \mathrm{a} \\
15.5 \pm 1.2 \mathrm{~b}\end{array}$ & $66.5 \pm 3.5 \mathrm{a}$ & \\
\hline & 42 & $176.5 \pm 13.6 b$ & $600.5 \pm 10.0 \mathrm{~b}$ & $22.5 \pm 0.3 b$ & $37.9 \pm 0.1 b$ & $\begin{array}{l}2.63 \pm 0.5 \mathrm{a} \\
13.8 \pm 1.9 \mathrm{~b}\end{array}$ & $63.8 \pm 4.5 \mathrm{a}$ & \\
\hline
\end{tabular}

$\pm \mathrm{SD}$

*Significant at $P<0.001$. Different letters in the same row indicate significant differences $(P<0.05 ; \mathrm{LSD})$ 
Table 7 Lactobacillus counts $\left(110^{7} \mathrm{CFU} / \mathrm{mL}\right)$ of EFY lacto-pickle

\begin{tabular}{lllllll}
\hline $\begin{array}{l}\text { Equilibrated salt } \\
\text { concentration (\%) }\end{array}$ & \multicolumn{6}{l}{ Fermentation (days) } \\
\cline { 2 - 7 } & 7 & 14 & 21 & 42 & 28 & 35 \\
\hline 0 & 1.0 & 1.0 & 0.9 & 0.8 & 0.7 & 0.4 \\
8 & 1.4 & 1.2 & 1.1 & 0.9 & 0.8 & 0.8 \\
10 & 1.2 & 1.0 & 1.0 & 0.7 & 0.7 & 0.6 \\
\hline
\end{tabular}

Genkawa et al. (2012). The main absorption peaks at 3390, 2931, 2500, 1670, 1167, and 899/cm in IR spectroscopy were generated in the fresh EFY lacto-pickle (Supplementary Fig. 1). The wider bands at $3390 / \mathrm{cm}$ can be ascribed to hydrogen bonded $-\mathrm{O}-\mathrm{H}-$ stretching vibration and at 2931/cm might be asymmetric stretching of alkyl $-\mathrm{C}-\mathrm{H}-$. Similarly, the peaks at $2500 / \mathrm{cm}$ are attributed to carboxylic acid $(-\mathrm{O}-\mathrm{H})$. The bands above $1670 / \mathrm{cm}$ exhibited strong coordination to one oxygen of each carboxyl $(\mathrm{C}(=\mathrm{O}) \mathrm{OH})$ group coordinated to facial sites and two $\mathrm{C}=\mathrm{O}$ bonds directing opposite from the surface (Panda et al. 2017). The peaks around 1167 and 899/cm were assigned to the vibration of acyl or phenyl $\mathrm{C}-\mathrm{O}$ and aromatic $\mathrm{C}-\mathrm{H}$ group, respectively. However, changes in fundamental regions of IR spectra of the lacto-pickle (after fermentation) were detected with new absorption peaks at 3650 and 2088/ $\mathrm{cm}$ indicating the occupancy of added organic functional groups. The formation of organic acids is ascribed to the substantial LA fermentation by L. plantarum (MTCC-1325). The peaks at 2945,2847 , and $887 / \mathrm{cm}$ might be due to the presence of aromatic carboxyl, hydroxyl, and $\mathrm{C}-\mathrm{H}$ groups. However, weak peaks of oxalate for EFY lacto-pickle confirm the successful decrease in anti-nutritional factor (acridity) due to LA fermentation.

\section{Analysis of volatile organic compounds}

GC-MS analysis is an accurate and time efficient technique for analysis of volatile compounds and has been used for detection of LA by other researchers (Panda et al. 2017). The distinctive flavor to lacto-pickle is mostly due to the presence of volatile compounds and hence, GC-MS was used for detection of the same. In total, 26 volatile compounds, including acids, alcohols, esters, and other compounds were detected in the sample (Tables 8 and 9; Supplementary Fig. 2). The compound phenol-2,4-bis(1,1-dimethylethyl), was detected with a maximum peak area up to $31.26 \%(\mathrm{~m} / \mathrm{z}=206.20)$, whereas lactic acid was found with a peak area of $1.29 \%(\mathrm{~m} / \mathrm{z}=83.10)$. However, the presence of other VOCs (e.g., bis(2-ethylhexyl) phthalate, 7,9-di-tert-butyl-1-oxaspiro(4,5)deca-6,9-diene2,8-dione, phenol, 4-nitro-2-diphenylphosphino-,2,5-di-tertbutyl-1,4-benzoquinone, etc.) was negligible in the sample. Although in uncooked/pre-fermented EFY tuber contain some toxic anti-nutrients such as raphides (composed of calcium oxalate crystals) (Behera and Ray 2016), none of the particular hazardous organic variety was detected in the EFY lacto-pickle. These results clearly indicate the modification or disintegration of these risky organic compounds during the progression of SmF fermentation.
Fig. 1 SEM photograph shows the topography and attachment of rod-shaped L. plantarum (MTCC-1325) to the surface of EFY lacto-pickle during the process of fermentation (on 21st day). Circle with arrows $=$ L. plantarum (MTCC-1325) attachment on the sample (EFY lacto-pickle)

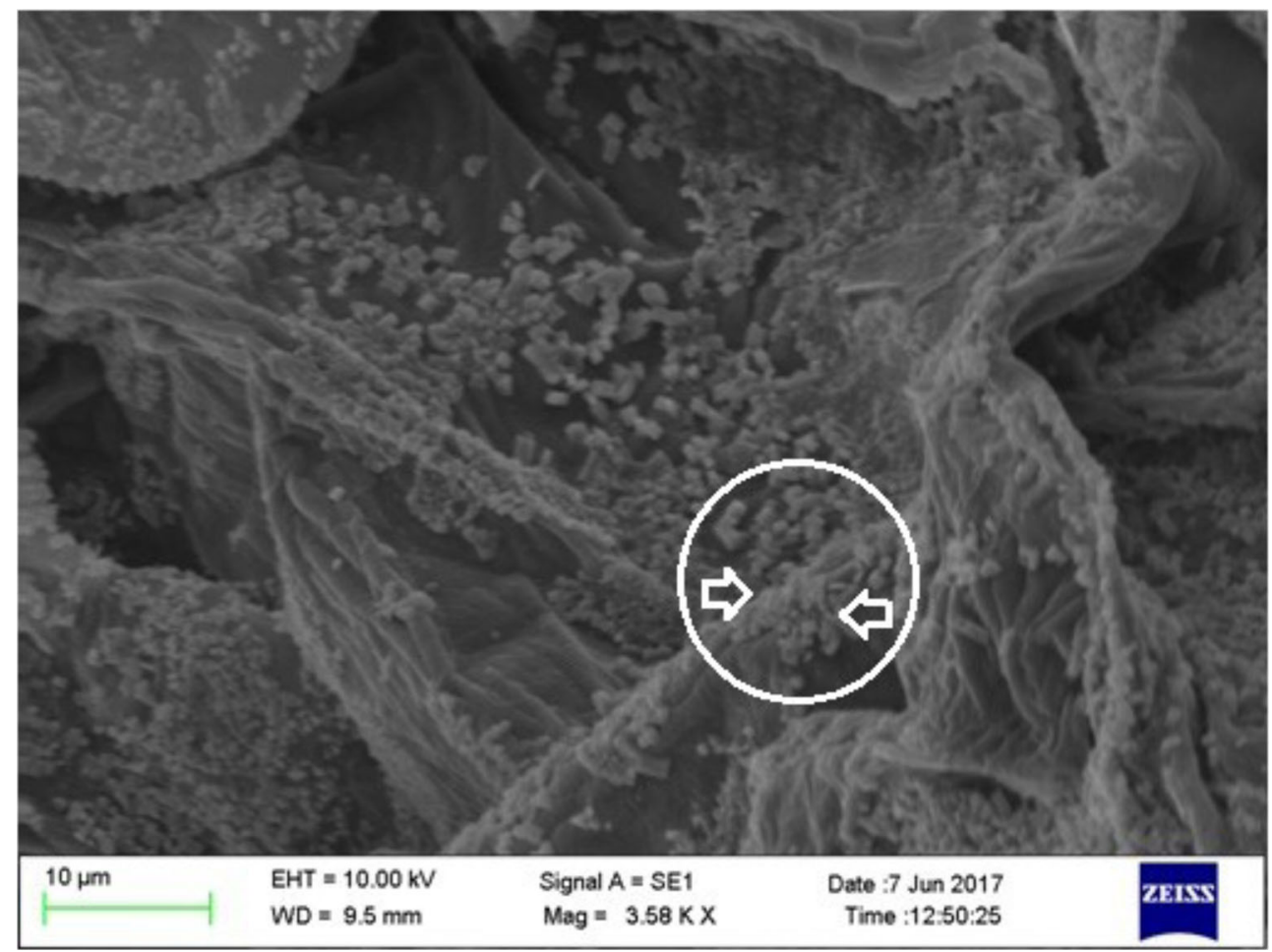


Table 8 Sensory evaluation of the EFY lacto-pickle in different salt concentrations

\begin{tabular}{|c|c|c|c|c|c|}
\hline \multirow[t]{2}{*}{ Attributes } & \multicolumn{5}{|c|}{ Equilibrated salt concentrations (\%) } \\
\hline & 2 & 4 & 6 & 8 & 10 \\
\hline Texture & $1.6 \pm 0.3 \mathrm{c}$ & $1.8 \pm 0.2 b$ & $2.9 \pm 0.4 \mathrm{c}$ & $3.5 \pm 0.5 b$ & $3.9 \pm 0.7 \mathrm{a}$ \\
\hline Aroma & $1.3 \pm 0.3 b$ & $1.5 \pm 0.4 b$ & $3.4 \pm 0.2 \mathrm{c}$ & $4.0 \pm 0.3 b$ & $4.7 \pm 0.5 \mathrm{a}$ \\
\hline Taste & $1.8 \pm 0.6 b$ & $1.9 \pm 0.4 b$ & $2.8 \pm 0.3$ & $3.4 \pm 0.6 \mathrm{a}$ & $4.3 \pm 0.3 b$ \\
\hline Color/appearance & $1.4 \pm 0.3 b$ & $1.8 \pm 0.4 \mathrm{c}$ & $2.6 \pm 0.3 b$ & $3.5 \pm 0.5 \mathrm{a}$ & $3.7 \pm 0.6 \mathrm{a}$ \\
\hline Flavor & $1.4 \pm 0.4 \mathrm{c}$ & $1.7 \pm 0.3 b$ & $2.7 \pm 0.3 b$ & $3.8 \pm 0.5 \mathrm{a}$ & $4.5 \pm 0.7 \mathrm{a}$ \\
\hline After taste & $1.4 \pm 0.3 \mathrm{c}$ & $1.7 \pm 0.4 \mathrm{c}$ & $2.8 \pm 0.3 b$ & $3.6 \pm 0.6 b$ & $4.0 \pm 0.7 b$ \\
\hline
\end{tabular}

Significant at $P<0.001$. Different letters in the same row indicate significant differences $(P<0.05 ; \mathrm{LSD})$

\pm SD

$n$ (no. of persons) $=100$

Values are means of the panelist's scores

1 dislike extremely, 2 like moderately, 3 like much, 4 like very much

\section{Antioxidant activity}

DPPH activity is frequently used for analysis of antioxidant property of foodstuff and plant extracts. In the present study, EFY lacto-pickle was observed to have a DPPH scavenging activity of $64.44 \pm 0.34 \%$, at a dose of $100 \mu \mathrm{L}$. The DPPH scavenging activities of EFY lacto-pickle was increased along with the fermentation period and was the duration-dependent manner up to 22 nd day fermentation using $L$. plantarum (MTCC-1325) (Fig. 2a). EFY lacto-pickle was found to be an effective DMPD $^{\circ+}$ radical scavenger in a concentration- dependent manner. It was able to scavenge $\mathrm{DMPD}^{\circ+}$ radicals by $66 \%$ at $10 \mu \mathrm{L}$ and $18 \%$ at $50 \mu \mathrm{L}$ of EFY lacto-pickle (Fig. 2b). The reducing power (FRAP assay) of the fermented pickle also increased with dose-dependent manner and found to be 0.716 and 1.132 for 100 and $300 \mu \mathrm{L}$, respectively, of EFY lacto-pickle (Fig. 2c).

\section{Sensory evaluation}

Consumer panel is a popular technique for assessing the acceptability of food products (Sivakumar et al. 2010). The sensory
Table 9 Compounds identified EFY lacto-pickle by GC-MS analysis

\begin{tabular}{llll}
\hline No & RT (min) & Compounds & RA (\%) \\
\hline 1 & 11.350 & Lactic acid & 1.29 \\
2 & 12.935 & Phenol, 2,4-bis (1,1-dimethylethyl)- & 31.26 \\
3 & 13.828 & 9-Hexadecene, (E)- & 2.83 \\
4 & 16.060 & 1-Octadecene & 3.78 \\
5 & 17.487 & 2,5-di-tert-Butyl-1,4-benzoquinone & 2.65 \\
6 & 17.819 & n-Hexadecanoic acid & 7.98 \\
7 & 18.083 & 1-Nonadecene & 3.42 \\
8 & 18.260 & Thiazolidine-2, 4-dione, 3-methyl-5-(3,4-methylenedioxybenzylideno)- & 4.13 \\
9 & 19.930 & Behenic alcohol & 2.49 \\
10 & 21.446 & Phenol, 4-nitro-2-diphenylphosphino & 4.05 \\
11 & 21.632 & Cyclotetracosane & 2.31 \\
12 & 22.919 & Bis (2-ethylhexyl) phthalate & 0.89 \\
13 & 22.976 & Triphenylphosphine oxide & 0.37 \\
14 & 23.205 & 9-Nonadecene & 3.38 \\
15 & 23.661 & Silane, dimethyldecyloxyhexadecyloxy- & 4.88 \\
16 & 23.729 & Triphenylphosphine sulfide & 1.79 \\
17 & 24.668 & Octacosanol & 2.21 \\
18 & 24.958 & 5-Methyl-2-trimethylsilyloxy-acetophenone & 0.50 \\
19 & 26.032 & Tris (tert-butyldimethylsilyloxy) arsane & 1.39 \\
20 & 26.359 & Trimethyl[4-(2-methyl-4-oxo-2-pentyl) phenoxy] silane & 0.26 \\
21 & 26.515 & Cyclotrisiloxane, hexamethyl- & 0.96 \\
22 & 26.603 & 1,4-Bis (trimethylsilyl) benzene & 0.43 \\
23 & 26.681 & Silicic acid, diethyl bis(trimethylsilyl) ester & 0.58 \\
24 & 27.023 & 5-Methyl-2-trimethylsilyloxy-acetophenone & 8.77 \\
25 & 27.065 & 1,2-Bis (trimethylsilyl) benzene & 5.98 \\
26 & 27.807 & 1,2-Benzisothiazol-3-amine tbdms & 1.41 \\
\hline
\end{tabular}

No. compound number in order of elution, $R T$ retention time (min), $R A$ relative area 
Fig. 2 Antioxidant activities of EFY lacto-pickles (a 2,2-

diphenyl-1-picryl-hydrazyl-hydrate (DPPH) free radical scavenging assay shows increase of scavenging activities with the fermentation period up to 22nd day of fermentation. $\mathbf{b} \mathrm{N}, \mathrm{N}-$ dimethyl-p-phenylenediamine (DMPD) scavenging capacity shows effective radical $\left(\mathrm{DMPD}^{\bullet+}\right.$ ) scavenger in a concentrationdependent manner of sample. c ferric reducing ability of plasma (FRAP) assay shows increase in reducing power with dosedependent manner of sample
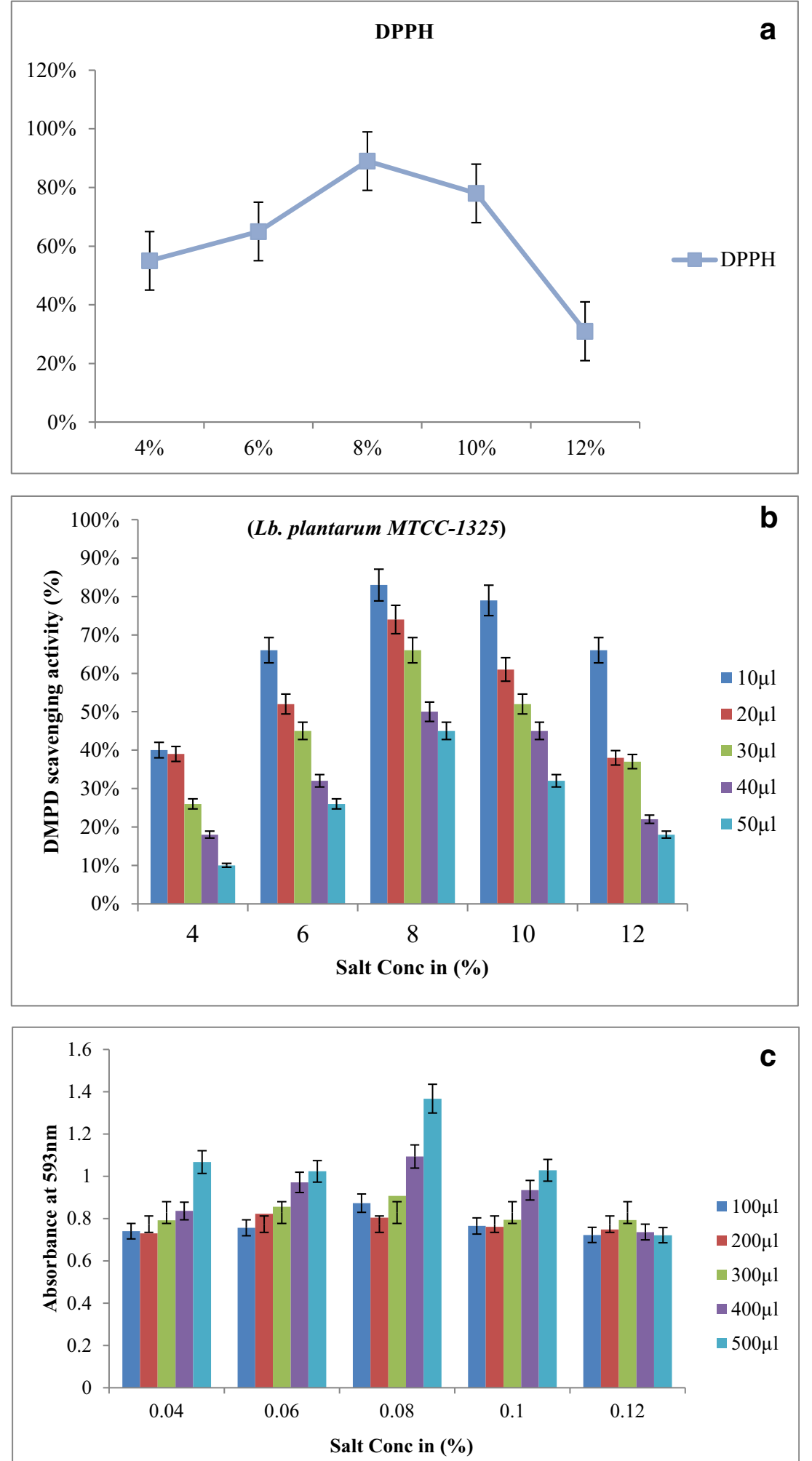

Ferric-reducing antioxidant power (FRAP) of EFY Lacto Pickles evaluation scores of EFY lacto-pickle with salt concentrations of $2-10 \%(w / v)$ were delivered to one-way analysis of variance (ANOVA). The reports showed a significant effect of salt ( $8 \%$, $w / v)$ concentrations on texture/smoothness $(F(4,10)=568.5$, $P<0.001)$; odor $(F(4,10)=717.9, P<0.001)$; taste $(F(4$, $10)=311.1, P<0.001)$; color $(F(4,10)=422.6, P<0.001)$; 
Fig. 3 Sensory evaluation shows the comparison of sensory scores of EFY lacto-pickles of various salt concentrations $(\mathrm{NaCl}, 2-$ $10 \%, w / v)$. The figure sights a significant effect of salt $(\mathrm{NaCl}$, $8 \%, w / v)$ concentrations on texture/smoothness, odor, taste, color, flavor, and after taste of sample (EFY lacto-pickle). No. of persons $=100$; Values are means of the panelist's scores; 1 = dislike extremely, 2 = like moderately, 3 $=$ like much, $4=$ like very much, 5 $=$ like extremely

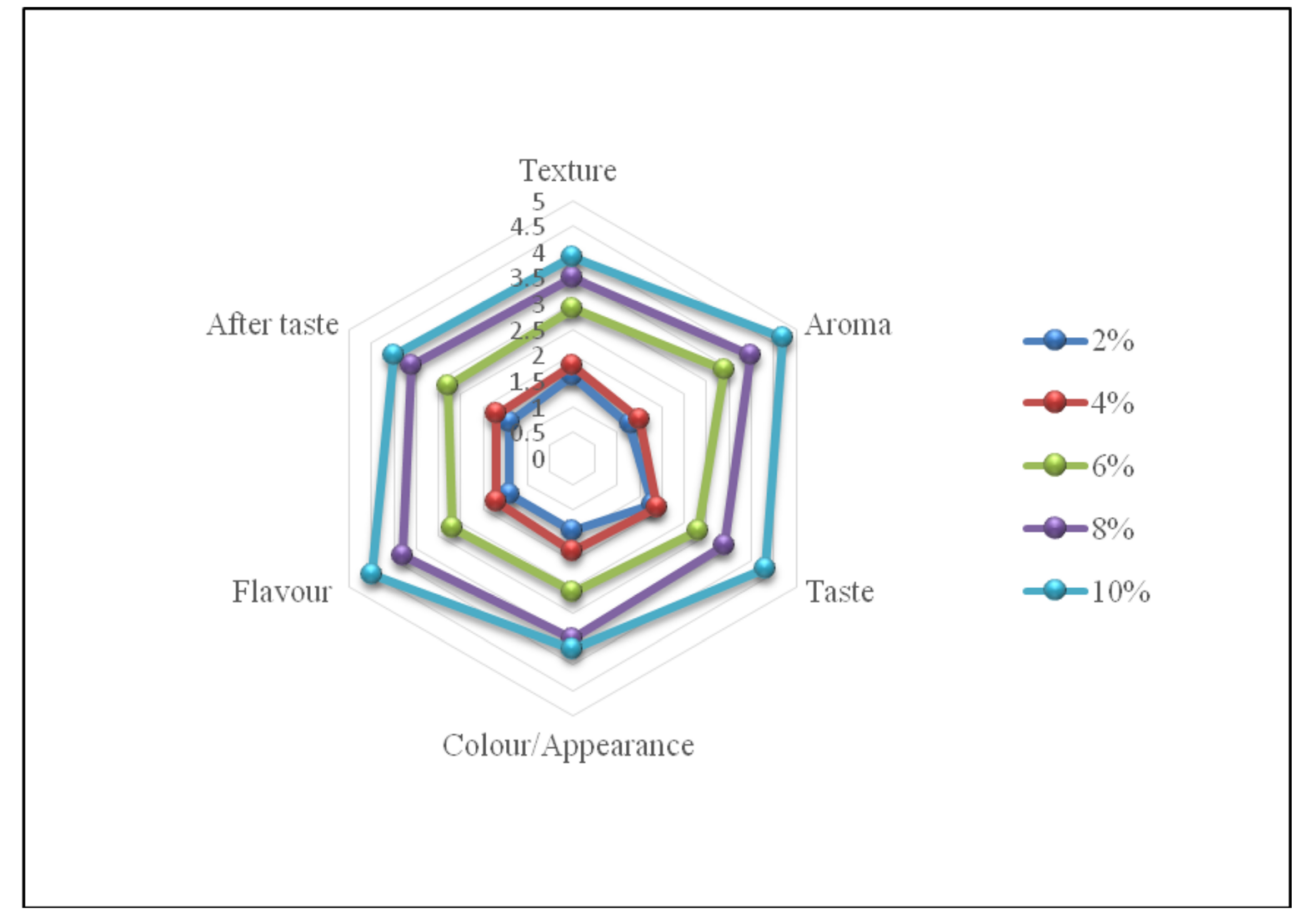

flavor $(F(4,10)=423.9, P<0.001)$; and after taste $(F(4,10)=$ 358.6, $P<0.001$ ) of EFY lacto-pickle (Table 8 and Fig. 3). Post hoc analysis exhibited that, except for $2 \%$ and $4 \%$ of salt concentration, all other combinations were significantly factious/ variant from each other $(P<0.05$; LSD). Furthermore, lacto- pickles processed in 8 and $10 \%$ saline/brine though were similar in some conditions, but aftertaste and taste wise pickles framed in $8 \%$ saline/brine was more preferable.

The correlation analysis was used for the measurement of the linear association between variables. The Pearson's
Fig. 4 The component plot in rotated space shows the graphical representation of principal components $(50.9 \%, \mathrm{PC} 1$ and $44.9 \%$, PC2) of analytical and proximate variables using varimax rotation with loading plot

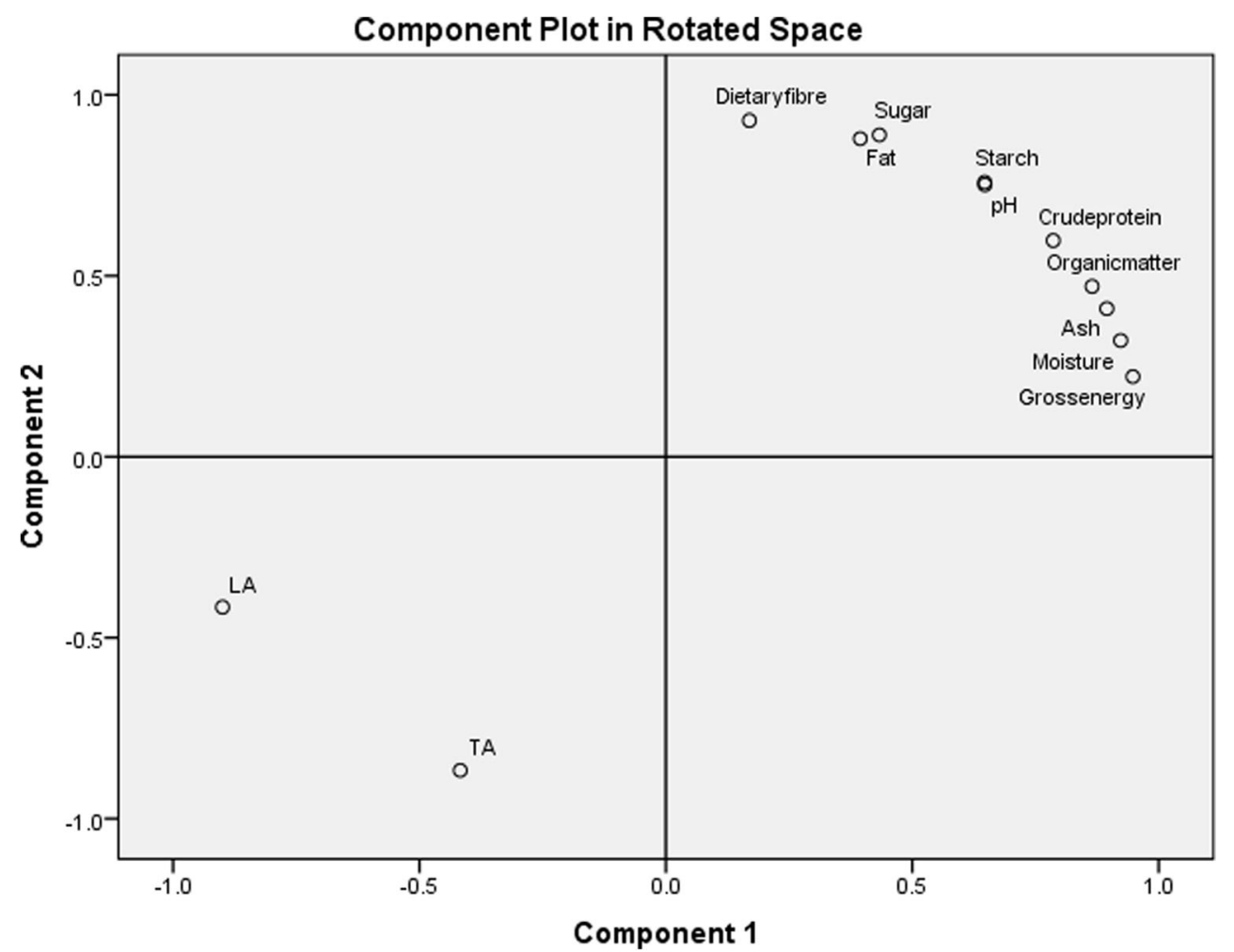


correlation coefficients $\left(r^{2}\right)$ among the analytical and proximate variables are presented in Supplementary Table 1. A significant correlation was observed between all the parameters. For instance, $\mathrm{pH}$ was observed to be significantly coordinated with LA and TA with the other important correlations are, such as starch-sugar (0.955), organic matter-gross energy (0.897), starch-protein (0.970), and contents of EFY lactopickle. Adopting PCA, the 12 original variables were shortened to two principal components/elementals (PC1 and PC2), which had eigenvalues more than 1 and kept for rotation. The variations observed were $50.9 \%$ and $44.9 \%$ for $\mathrm{PC} 1$ and $\mathrm{PC} 2$, respectively. The combination of $\mathrm{PC} 1$ and $\mathrm{PC} 2$ in coexisting reported for $94 \%$ of the overall variations. Further, the varimax method was used to rotate the factor pattern which was helpful for interpretation of dimensions. All the variables were loaded heavily on two dimensions. Five variants/variables, i.e., pH (+ve), TA (+ve), starch (+ve), sugar (+ve), and dietary fiber (+ve) were loaded heavily on PC2, showing strong correlations with these traits/attributes (Supplementary Table 2). Hence, the unite of these traits/variables loading on PC2 may be widely assigned to as nutrient axis or taste axis as these components are developing on major supplements/ nutrients in EFY lacto-pickle. A more detailed understanding informs that the factor loadings of organic matter $(+v e)$, crude protein $(+v e)$, gross energy $(+v e)$, and moisture $(+v e)$ may be annotated as carbon axis. Figure 4 depicts the plotting of PC1 against PC2 which highlights a similar trend. It is noteworthy that, till date, only a few reports have been published for application of PCA in the estimation of lacto-fermented foodstuff analysis (Panda et al. 2009, 2017).

\section{Conclusions}

The present investigation caters adequate scientific evidence for enhancement of the functional aspects and simultaneous preservation/storage of EFY lacto-pickle for an extended time period. Consumption of EFY lacto-pickle formed from SMF fermentation of blanched cubes in common salt $(\mathrm{NaCl}, 8 \%, w /$ v) solution can be a rich source of nutrients and beneficial attributes. Further, reports suggest the production of antimicrobial substances such as $\mathrm{H}_{2} \mathrm{O}_{2}$, LA, alcohols $(-\mathrm{OH})$, and alternative metabolites from EFY lacto-pickle, which may inhibit unsolicited pathogens in the human intestine. Additionally, the EFY lacto-pickle is a novel functional and fermented product containing nutritious and antioxidant factors. The biochemical and sensory attributes of EFY lactopickle also had encouraging results among the consumers and hence carry worthy anticipation for commercialization among small and cottage-scale industries. The overall results obtained in this study warrant further investigation of probiotic properties of $L$. plantarum (MTCC-1325) for enhancing functional properties of EFY lacto-pickles.
Acknowledgments We are incredibly grateful to the support provided by National Institute of Technology Raipur, India, and North Orissa University, Odisha, India, for providing the facility, space, and opportunity for this work.

\section{Compliance with ethical standards}

Conflict of interest The authors declare that they have no competing interests.

\section{References}

Amerine MA, Ough CS (1980) Methods for analysis of musts and wine. Wiley, New York

Arva HR, Bhaskar JJ, Salimath PV, Mallikarjuna AS (2013) Anti-diabetic effect of elephant-foot yam (Amorphophallus paeoniifolious (Dennst.) Nicolson) in Streptozotocin-induced diabetic rats. Int J Biomed Pharm Sci 7:1-6

Behera SS, Ray RC (2016) Konjac glucomannan, a promising polysaccharide of Amorphophallus konjac K. Koch in health care. Int J Biol Macromol 92:942-956

Behera SS, Panda SH, Mohapatra S, Kumar A (2018) Statistical optimization of elephant foot yam (Amorphophallus paeoniifolius) lactopickle for maximal yield of lactic acid. LWT Food Sci Technol 87: $342-350$

Behera SS, Ray RC, Zdolec N (2018a) Lactobacillus plantarum with functional properties: an approach to increase safety and shelf-life of fermented foods. Biomed Res Int. https://doi.org/10.1155/2018/ 9361614

Benzie IFF, Strain JJ (1996) The ferric reducing ability of plasma (FRAP) as a measure of "antioxidant power": the FRAP assay. Anal Biochem 239:70-76

Bernet MF, Brassart D, Neeser JR, Servin AL (1994) Lactobacillus acidophilus LA 1 binds to cultured human intestinal cell lines and inhibits cell attachment and cell invasion by enterovirulent bacteria. Gut 35:483-489

Di Cagno R, Coda R, De Angelis M, Gobbetti M (2013) Exploitation of vegetables and fruits through lactic acid fermentation. Food Microbiol 33:1-10

Dubey RC, Maheshwari DK (2004) Practical manual of microbiology. Nirali publication, Pune

Fogliano V, Verde V, Randazzo G, Rittieni A (1999) Method for measuring antioxidant activity and its application to monitoring the antioxidant capacity of wines. J Agric Food Chem 47:1035-1040

Gardner NJ, Savard T, Obermeier P, Caldwell G, Champagne CP (2001) Selection and characterization of mixed starter cultures for lactic acid fermentation of carrot, cabbage, beet and onion vegetable mixtures. Int J Food Microbiol 64:261-275

Genkawa T, Watari M, Nishii T, Ozaki Y (2012) Development of a nearinfrared/mid-infrared dual-region spectrometer for online process analysis. Appl Spectrosc 66:773-781

Hoover R (2001) Composition, molecular structure, and physicochemical properties of tuber and root starches: a review. Carbohydr Polym 45: 253-267

Joshi VK, Somesh S (2010) Preparation and evaluation of sauces from lactic acid fermented vegetables. J Food Sci Technol 47:214-218

Liu SQ (2003) Practical implications of lactose and pyruvate metabolism by lactic acid bacteria in food and beverage fermentations. Int $\mathrm{J}$ Food Microbiol 83:115-131 
Mahadevan A, Sridhar R (1998) Methods in physiological plant pathology, 5th edn. Sivakami Publication, Madras

Marxen K, Vanselow KH, Lippemeier S, Hintze R, Ruser A, Hansen UP (2007) Determination of DPPH radical oxidation caused by methanolic extracts of some microalgal species by linear regression analysis of spectrophotometric measurements. Sensors 7:2080-2095

Montet D, Loiseau G, Zakhia-Rozis N (2006) Microbial technology of fermented vegetables. In: Ray RC, Ward OP (eds) Microbial biotechnology in horticulture, Volume 1. Science Publishers Inc., Enfield, pp 309-343

Mugula JK, Narvhus JA, Sørhaug T (2003) Use of starter cultures of lactic acid bacteria and yeasts in the preparation of togwa, a Tanzanian fermented food. Int J Food Microbiol 83:307-318

Muniz CR, Borges MF, Freire FCO (2008) Tropical and subtropical fruit fermented beverages. In: Ray RC, Ward OP (eds) Microbial biotechnology in horticulture, vol 3. Science Publishers, New Hampshire, pp 35-70

Ogunjobi AA, Adebayo-Tayo BC, Ogunshe AA (2005) Microbiological, proximate analysis and sensory evaluation of processed Irish potato fermented in brine solution. Afr J Biotechnol 4:1409-1412

Panda SH, Ray RC (2007) Lactic acid fermentation of $\beta$-carotene rich sweet potato (Ipomoea batatus L.) into lacto- juice. Plant Food Hum Nutr 62:65-70

Panda SH, Ray RC (2008) Direct conversion of raw starch to lactic acid by Lactobacillus plantarum MTCC 1407 in semi-solid fermentation using sweet potato (Ipomoea batatas L.) flour. J Sci Ind Res 67:531537

Panda SH, Panda S, Shiva Kumar PS, Ray RC (2009) Anthocyanin-rich sweet potato lacto-pickle: production, nutritional and proximate composition. Int J Food Sci Technol 44:445-455

Panda SK, Behera SK, Qaku XW, Sekar S, Ndinteh DT, Nanjundaswamy HM, Ray RC, Kayitesi E (2017) Quality enhancement of prickly pears (Opuntia sp.) juice through probiotic fermentation using lac- tobacillus fermentum-ATCC 9338. LWT Food Sci Technol 75:453459

Prosky L, Asp NG, Furda I, DeVries JW, Schweizer TF, Harland BF (1984) Determination of total dietary fiber in foods and food products: collaborative study. J Assoc Off Anal Chem 68:677-679

Ray RC, Behera SK (2016) Amorphophallus: Technological interventions. In: Sharma HK (ed) Tropical tuber crops: technological interventions. Wiley, pp 591-612

Reddy G, Altaf MD, Naveena BJ, Venkateshwar M, Kumar EV (2008) Amylolytic bacterial lactic acid fermentation - a review. Biotechnol Adv 26:22-34

Reddy CK, Haripriya S, Mohamed AN, Suriya M (2014) Preparation and characterization of resistant starch III from elephant foot yam (Amorphophallus paeonifolius) starch. Food Chem 155:38-44

Sharma A, Satyanarayana T (2013) Microbial acid-stable $\alpha$-amylases: characteristics, genetic engineering and applications. Process Biochem 48:201-211

Sivakumar PS, Panda SH, Ray RC, Naskar SK, Bharathi LK (2010) Consumer acceptance of lactic acid fermented sweet potato pickle. J Sens Stud 25:706-719

Tominaga M, Sato K (1996) Lactic acid fermentation of saccharified solution from rice flour. J Food Sci 61:627-631

USDA (1984) Composition of foods, vegetables and vegetable products raw processed, prepared. Agricultural hand book, Department of agriculture, Washington, DC

Wang CY, Lin PR, Ng CC, Shyu YT (2010) Probiotic properties of Lactobacillus strains isolated from the feces of breast-fed infants and Taiwanese pickled cabbage. Anaerobe 16:578-585

Zhang JH, Hu F, Chen HY (2000) Processing technique of vegetable juice beverage of Sechium edule Swartz and fermentation beverage of Cucurbita moschata. Duch J Shanghai Agric Coll 18:114-117

Publisher's note Springer Nature remains neutral with regard to jurisdictional claims in published maps and institutional affiliations. 